\title{
Vermicompost Nutrient Composition and It's Influence on Productivity and Quality of Cabbage (Brassica Oleracea Var. Capitata ) and Tomato ( Solanum lycopersicum ): A Review
}

\author{
Geletaw Kebede \\ College of Agriculture, Department of horticulture, Wolaita Sodo University, P.O.BOX: 138,Wolaita Sodo, \\ Ethiopia
}

\begin{abstract}
To feed ever increasing population enhancing productivity by sing integrated agricultural practices are paramount important. Among agricultural practice production of horticultural crops vegetables crops are the major one. To obtain significant yield, quality of agricultural products having suitable and fertile soil is paramount important. To increase production and productivity using technology that increase production and productivity of crops with affordable cost for the growers, sustainable production and sound for the environment. According to researchers finding, vermicompost can prepared from organic materials by decomposing organic inputs decomposer, worms. As several research finding indicates that proportion of nutrient available in vermicompost are higher than other organic materials. Furthermore application of vermicompost increased productivity of cabbage and tomato as well. As different Authors finding showed that the vermicompost with recommended doses of chemical fertilizers was suitable for the improved growth and yield of cabbage and tomato. The highest yield were obtained from the crop which was planted in treatment three. Vermicompost in addition to fertilizers ensured favorable condition for the yield of cabbage and tomato crops.
\end{abstract}

Keywords: Vermicompost. Cabbage, Tomato, nutrient composition, Growth, Yield

DOI: $10.7176 / \mathrm{JNSR} / 10-1-03$

Publication date: January $31^{\text {st }} 2020$

\section{INTRODUCTION}

Most smallholder farmers in Africa appreciate the value of fertilizers, but they are seldom able to apply them at the recommended rates and at the appropriate time because of high cost, lack of credit, delivery delays, and low and variable returns (Garg, et al.; 2006). Organic inputs are often proposed as alternatives or integrated application to mineral fertilizers. However, the traditional organic inputs, crop residues, and animal manures cannot meet crop nutrient demand over large areas because of the limited quantities available, the low nutrient content of the materials, and the high labor demands for processing and application. Therefore, farmers should use integrated organic and inorganic inputs (Alemu et al., 2016).

A green revolution improve the production and productivity in developing countries, however it had also a number of harmful ecological consequences such as depletion of lands, decline soil fertility, soil salinisation, soil erosion, deterioration of environment, health hazards, and poor sustainability of agricultural lands and degradation of biodiversity. Today agriculture work seeks new management methods and technologies to mitigate the current and future needs and limitation. The new methods should be productive and cost effective, but moreover must be particularly ecologically sustainable (Caffey et al., 2001)

Organic farming is the form of agriculture that relies on the use of compost, green manure, vermicompost, farmyard manure, poultry manure and reduces the use of synthetic farm inputs (Magagula et al., 2010). This is essential to restore the carbon level in the soils where the depletion of carbon takes place at rapid rate. Fixen and Vivekananda (2010) stated that, when vermicompost is fortified with mineral fertilizers and applied to sweet potato, there will be higher increase in crop yield. This increase in yield has been attributed to the increment N, P, K and $\mathrm{Ca}$ uptake by sweet potato. Vermicomposting is an easy technology, environmentally-friendly process which converts wastes to a wider range organic fertilizer. Vermicompost is the worm's casting; highly nutritive 'organic fertilizer' and more powerful 'growth promoter'. It is a soil fertility booster; improve soil property, restores natural fertility against the 'destructive' chemical fertilizers. It is rich in nitrogen phosphorus, potassium, organic carbon, sulphur, hormones, vitamins, enzymes and antibiotics which help to improve the quality and quantity of yield (Thiruneelakandan and Subbulakshmi, 2014). It is widely used to treat soil acidity, salinity and alkalinity; retains nutrients for long time, binds heavy metals and contaminants. Vermicompost can be processed from most organic wastes such as animal manures, green plants, crop residues, ash and any decomposable organic waste through interactions between earthworms and microorganisms, (Magagula et al., 2010). They have high and diverse enzymatic and microbial activities. This organic fertilizer is therefore increasingly considered in agriculture and horticulture as a promising alternative to chemical fertilizers. However, most farmers in Ethiopia yet do not know how to prepare and use vermicompost either in combination with mineral fertilizers or alone for different crops. Accordingly, the yield has been declined and the crop is turn out to be replaced by other crops . In considering of 
this fact, providing complied information about the role of vermicompost fertilizer is paramount importance for rationalizing the application of vermicompost to improve the yield and quality of cabbage and tomato. This review is therefore, initiated with the following objectives. To provide confined information to growers about role of vermicompost in order to maximize yield and nutritional quality of cabbage and tomato with low production cost.

\section{LITERATURE REVIEW}

\subsection{The crop}

Cabbage (Brassica oleracea var.capitata) is the second most important cole crop flowed by cauliflower, which was originated in Europe and in the Mediterranean region, evolved from a leafy mustard herb "Caboche"a French word believed to be the root of the English name of cabbage and is derived from the Normanno picard word which means "head". Cabbage falls under cole group and all cole crops have one common trait i.e., genetic potential to thicken various parts. Cabbage is differentiate by its swollen heads which is formed by thickening of edible buds with tightly packed overlapping leaves manifesting a large head. The shape of head may be round, conical, oblong and flat or Savoy depending on the variety.

Cabbage is one of the most important, popular and widely grown cole crop in the world and abroad and is well known for its nutritive value. It contains a range of essential vitamins and minerals as well as small amount of protein with good caloric value. In recent years vegetable consumption has increased. However, the productivity of cabbage per unit area is quite low in developing countries as compared to the developed countries of the world. Among the various factors involved nutrient supply is an important inputs for realizing higher cabbage head yield, its nutrient content as well as its seed yield.

\subsection{Climatic Requirements of Cabbage}

Cabbage and leafy greens are adapted to a wide range of environmental conditions and are grown. Cabbage, collard and kale can tolerate hard frosts, but severe freezes can be damaging. Turnip and mustard can tolerate fairly cold temperatures, but hard frosts can kill the crops or make them unmarketable. All can be grown on a wide range of soil types and are somewhat drought tolerant, although production without irrigation is not recommended. Most production of cabbage and leafy greens occurs in the spring, fall and winter months, except in the north-ern reaches of the state where production occurs in spring and summer.

\subsection{Vermicompost}

Vermicompost is the product or process of composting using various worms, usually red wigglers, white worms, and other earthworms, to create a heterogeneous mixture of decomposing vegetable or food waste, bedding materials, and vermicast, which are also called worm castings, worm humus or worm manure. It is the end-product of the breakdown of organic matter by an earthworm. These castings have been shown to contain reduced levels of contaminants and a higher saturation of nutrients than do organic materials before vermicomposting.

Containing water-soluble nutrients, vermicompost is an excellent, nutrient-rich organic fertilizer and soil conditioner. While there are nutrients in worm castings, the real benefit to worm castings are the millions of beneficial microbes that they contain. Those microbes eat organic matter in the soil and release available plant nutrients. Fungi in the castings form symbiotic relationships to transport water and nutrients to the roots. They can also hold water in the soil and help with water management. Worm castings have at least 10 times more microbes than soil or regular compost. While vermicomposting is generally known as a nutrient rich source of organic compost used in farming and small scale sustainable, organic farming, the process of vermicasting is being studied as a treatment for organic waste in sewage and wastewater plants around the world .Worms eat food scraps, which become compost as they pass through the worm's body. Compost exits the worm through its tail end. This compost can then be used to grow plants. Vermicompost is good for plants because the worms are eating nutrient-rich fruit and vegetable scraps and turning them into nutrient-rich compost. One of the main goals of every organic farmer is to build long-term soil fertility and tilth by feeding the soil with a variety of natural amendments. The regular addition of compost is one of the best ways to enhance the soil's organic and humic content, which helps to build a fertile soil structure. This soil structure makes better use of water and nutrients. It is easier to till and, overall, is better able to achieve optimum yields on a long-term basis.

Since compost has already decomposed, its impacts are much more long-lasting than crop residues and green or animal manures that rapidly degrade when added to the soil. Composting also gives farmers a way to recycle manures and plant residues that otherwise might present some environmental problems. Compost is produced through the activity of aerobic (oxygen requiring) microorganisms. These microbes require oxygen, moisture, and food in order to grow and multiply. When these factors are maintained at optimal levels, the natural decomposition process is greatly accelerated. The microbes generate heat, water vapor, and carbon dioxide as they transform raw materials into a stable soil conditioner.

Compost has the unique ability to improve the properties of soils and growing media physically (structurally), 
chemically (nutritionally), and biologically. Other compost benefits include: Improves the soil structure, porosity, and density, thus creating a better plant root environment increases infiltration and permeability of heavy soils, thus reducing erosion and runoff, Improves water holding capacity, thus reducing water loss and leaching in sandy soils, supplies a variety of macro and micronutrients, may control or suppress certain soil-borne plant pathogens, supplies significant quantities of organic matter, improves cation exchange capacity (CEC) of soils and growing media, thus improving their ability to hold nutrients for plant use, supplies beneficial microorganisms to soils and growing media, improves and stabilizes soil $\mathrm{pH}$ and Can bind and degrade specific pollutants. Although the most common way to produce compost is using microorganisms, compost can be also produced using worms. This is called worm compost or vermicompost. This kind of compost is a highly valued, and is often called black gold. This is because there are not many farmers involved in worm compost production and it takes time to produce.

\begin{tabular}{llll}
\hline S.NO. & Nutrients & Cattle Dung Compost & Vermicompost \\
\hline $\mathbf{1}$ & Nitrogen & $0.4-1.00$ & $2.5-3.0 \%$ \\
$\mathbf{2}$ & Phosphorus & $0.4-.08$ & $1.8-2.9 \%$ \\
$\mathbf{3}$ & Potassium sulfate & $0.8-12 \%$ & $1.4-2 \%$ \\
\hline
\end{tabular}

Table 3. NPK value of vermicompost compared with conven-tional cattle dung compost made from cattle dung Chandan singh ahirwar, vol I, 2015

As the above data indicated amount of nitrogen, phosphorus and potassium sulfate nutrients which were existed in vermicompost in more than nutrients were existed cattle dung compost. Therefore in addition to recommended rate of fertilizer, application of vermicompost is essential to achieve a better yield of the crops. Table2. Comparison between nutritive values of the end products of conventional composting and vermicomposting systems (CNP in \%; Others in $\mathrm{mg} / 100 \mathrm{gm}$ of compost).

\begin{tabular}{llcc}
\hline S.NO. & Parameter & Conventional Composting(\%) & Vermicomposing(\%) \\
\hline $\mathbf{1}$ & Total Carbon $(\mathrm{C})$ & 9.34 & 13.5 \\
$\mathbf{2}$ & Total Nitrogen $(\mathrm{N})$ & 1.05 & 1.33 \\
$\mathbf{3}$ & Available Phosphorus (P) & 0.32 & 0.47 \\
$\mathbf{4}$ & Iron (Fe) & 587.87 & 746.2 \\
$\mathbf{5}$ & Zinc (Zn) & 12.7 & 16.19 \\
$\mathbf{6}$ & Magnesium $(\mathrm{Mg})$ & 689.32 & 832.48 \\
$\mathbf{7}$ & Copper $(\mathrm{Cu})$ & 4.42 & 5.16 \\
\hline
\end{tabular}

Source : S Ali, effect of Vermicompost on the Growth and Yield of Cabbage, 2018.

The Author found that the proportion of all plant nutrients which existed in vericompost were higher as compare to conventional composting. Hence, the Author gave recommendation to growers to use vermicompost and recommended fertilize as well in order to obtain successful production and productivity of cabbage and tomato. Fresh weight of whole plant

According to the Authors finding the highest fresh weight of whole plant was recorded from treatment three (2306.67 g plant-1) and the lowest fresh weight of whole plant was recorded from treatment four (Table 3). (S Ali, 2018, Chinanshuk Ghosh et al , 2009, Noor et al.,)

\section{Fresh weight of head}

Marketable fresh head weight of cabbage varied among the treatments for their combinations. The highest fresh head weight (1263.67 g plant-1) was recorded in treatment three which was statistically similar with treatment two (1170.63 g plant-1) and the lowest (589.50 g plant-1) was recorded in treatment four .( Daudaet et al., Tomati, et al.., 1998 , Daly 1995 )

\section{Diameter of head}

Diameter of head was significantly influenced by different vermicompost . It is evident that the highest diameter of head $(25.67 \mathrm{~cm})$ was obtained with the treatment three, which was statistically identical with treatment two.. The lowest diameter of head was measured with treatment four (Nyambo, et al.., Oruku et al..,2001 Rashid et al.., 1993)

Table 3: Impact of vermicompost on the yield stages of cabbage

\begin{tabular}{llllll}
\hline Treatment Fresh weight of whole pla & $\begin{array}{l}\text { Freshweight } \\
\text { nt (g plant-1) }\end{array}$ & $\begin{array}{c}\text { Fresh } \\
\text { of loose leaves } \\
\text { (g plant-1) }\end{array}$ & $\begin{array}{c}\text { Dead weight } \\
\text { (g plant-1) }\end{array}$ & $\begin{array}{c}\text { Diameter } \\
\text { of head } \\
\text { (cm) }\end{array}$ & $\begin{array}{c}\text { Yield } \\
\text { ( ton/ha) }\end{array}$ \\
\hline T1 & 1657.67 & 821.00 & 836.67 & 24.50 & 27.89 \\
T2 & 2256.63 & 1043.0 & 1170.63 & 25.00 & 39.2 \\
T3 & 2306.67 & 1086.0 & 1263.67 & 25.67 & 42.12 \\
T4 & 1161.50 & 572.00 & 589.50 & 15.35 & 19.6 \\
\hline
\end{tabular}

$\mathrm{T} 1=\operatorname{Urea}(392 \mathrm{~kg} / \mathrm{ha}), \mathrm{T} 2=\operatorname{Urea}(392 \mathrm{~kg} / \mathrm{ha}+$ Cowdung $(5 \mathrm{t}$ ha-1); T3 =T1+ Vermicompost $(5 \mathrm{t}$ ha- 1$)$; T4= T1+ Vermicompost (10 tha-1) 


\section{Yield of cabbage}

As researchers finding the highest yield (42.12 t ha-1) was obtained from the crop which was planted in treatment three and the lowest yield was obtained from the crop which was planted in treatment four(Table 3)( Getnet and Raja (2013), . Sinha, et al, 2010).

\section{Growth and Yield Parameters of tomato :}

Based on the reviewed data that was compiled from different research finding which conducted in different agro ecology in container, the highest plant height of tomato was recorded from VC $45 \%$ followed by VC30 and VC15\% but the lowest plant height obtained from control one( Rakesh Joshi and Adarsh Pal Vig, 2010). This finding indicated that when the proportion of vermicompost increase, the length of the plant also increase as well. Table4. Effect of vermicompost on plant height $(\mathrm{cm})$ yield per plant $(\mathrm{kg})$,total plant biomass yield $(\mathrm{kg} / \mathrm{plant})$, of tomato using pot containers

\begin{tabular}{lllll}
\hline Sno. & Treatments & Plant height $(\mathrm{cm})$ & $\begin{array}{l}\text { Yield } \\
(\mathrm{Kg} / \text { plant})\end{array}$ & $\begin{array}{l}\text { Total biomass yield } \\
\text { ( kg/plant) }\end{array}$ \\
\hline $\mathbf{1}$ & Soil ( control) & 38.0 & 0.36 & 19 \\
$\mathbf{2}$ & VC15 (Soil + 15\%VC) & 63.0 & 0.61 & 37 \\
$\mathbf{3}$ & VC30 ( Soil + 30\% VC) & 63.4 & 0.79 & 39 \\
$\mathbf{4}$ & VC45 (Soil + 45\% VC) & 63.5 & 0.85 & 42.00 \\
\hline
\end{tabular}

Source; Rakesh Joshi et al 2010, Grappelliet al 1989

According to the Authors research finding, total yield $/$ plant $(\mathrm{kg})$ the highest yield $(0.85 \mathrm{~kg} / \mathrm{plant})$ was recorded from $\mathrm{VC} 45 \%$ while the least was recorded from a treatment that was not applied vermicompost. Other finding also revealed application different concentrations of vermicompost enhanced earthworm composts as plant growth media in the yields of strawberry fruits significantly .

Table 5. Effect of vermicompost on PH, soluble solid(\%), insoluble solid(\%), ascorbic acid (mg/kg) of tomato using pot containers growing system

\begin{tabular}{llcccc}
\hline S. no. & Treatments & PH & Soluble solid & Insoluble solid & Ascorbic acid \\
\hline $\mathbf{1}$ & Soil ( control) & 4.1 & 4.57 & 3.29 & 115 \\
$\mathbf{2}$ & VC15 (Soil + 15\%VC) & 4.8 & 5.48 & 3.98 & 131 \\
$\mathbf{3}$ & VC30 ( Soil + 30\% VC) & 4.5 & 5.89 & 4.44 & 141 \\
$\mathbf{4}$ & VC45 (Soil + 45\% VC) & 5.0 & 5.93 & 4.16 & 145 \\
\hline
\end{tabular}

Source: S Ali, 2018

Quality Parameters:According to the Authors conclusion that discussed in the above table, it is clear that vermicompost in can effectively enhance germination, growth, yield and quality of tomatoes by improving various physical, chemical and biological properties of the soil

\section{SUMMARY AND CONCLUSION}

Agriculture is a backbone to build sustainable economy of a given country particularly for developing countries at this time. Among agricultural practice production of horticultural crops vegetables crops are the major one. To obtain significant yield, quality of agricultural products having suitable and fertile soil is paramount important. To increase production and productivity using technology that increase production and productivity of crops with affordable cost for the growers, sustainable production and sound for the environment. According to researchers finding, vermicompost can prepared from organic materials by decomposing organic inputs decomposer, worms. As several research finding indicates that proportion of nutrient available in vermicompost are higher than other organic materials. Furthermore application of vermicompost increased productivity of cabbage and tomato as well.

As different Authors finding showed that the vermicompost with recommended doses of chemical fertilizers was suitable for the improved growth and yield of cabbage and tomato. The highest yield (42.12 t ha-1) was obtained from the crop which was planted in treatment three. Vermicompost in addition to fertilizers ensured favorable condition for the yield of cabbage.

\section{REFERNCES}

Anonymous., Effect of chemical fertilizer and organic manure on the yield and quality of cabbage. Annual Rep., BARI, Joydebpur. 2006. pp. 186-189.

Caffey, R. H., Kazmierczak, R. F. and Avault, J. W. (2001), “Incorporating Multiple Stakeholder Goals into the Development and Use of a Sustainable Index:Consensus Indicators of Aquaculture Sustainability'.Department of Ag. Econ and Agribusiness of Louisiana State University, USA. Staff Paper, pp. 8-40.

Daly, P., and Tomkins, B., Literature prepared for the rural industries research and development Corporation. Institute for horticultural development, Private bag 15, South eastern mail centre, Victoria, 1995. p. 3176 
Nyambo, B., and Lohr, B., The role and significance of farmer participation in biocontrol-based IPM for brassica crops in East Africa. In: Hoddle, M.S. (Ed.).Proceedings of the Second International Symposium on Biological Control of Arthropods vol.I, 12-16 September, Davos, Switzerland. 2005. pp. 290-301

Oruku, L., and Ndungu, B., Final socio- economic report for the periurban vegetable IPM thematic cluster. CABI Africa Regional Centre Report, Nairobi.2001. 49p.

Rakesh Joshi and Adarsh Pal Vig,2010 Effect of Vermicompost on Growth, Yield and Quality of Tomato (Lycopersicum esculentumL), African Journal of Basic \& Applied Sciences 2 (3-4): 117-123

S Ali and MA Kashem, effect of Vermicompost on the Growth and Yield of Cabbage, p-ISSN: 2350-0085; eISSN: 2350-0263; Volume 5, Issue 1; January-March, 2018 pp. 45-49 